\title{
Enrichment of Polyunsaturated fatty acids from catfish oil with immobilized Rhizopus oryzea lipase
}

${ }^{1}$ Ho Chi Minh City Open University, Vietnam

*Corresponding author: hien.ltm@ou.edu.vn

\begin{tabular}{|c|c|}
\hline ARTICLE INFO & ABSTRACT \\
\hline $\begin{array}{l}\text { DOI:10.46223/HCMCOUJS. } \\
\text { tech.en.8.1.334.2018 }\end{array}$ & $\begin{array}{l}\text { Nowadays, Pangasius hypophthalmus fillet is one of the } \\
\text { main marine products in the Vietnamese Mekong River Delta with } \\
\text { over three hundred thousand tons per year. One of the byproducts } \\
\text { of this industry is fat, about one hundred thousand tons per year. } \\
\text { That byproduct has been only used in the animal foodstuff } \\
\text { industry after oil extracting or it becomes waste. In order to }\end{array}$ \\
\hline Received: September $13^{\text {th }}, 2017$ & increase the quality of Pangasius hypophthalmus oil, we have \\
\hline Revised: April $4^{\text {th }}, 2018$ & enriched PUFA in the oil by hydrolysis with immobilized \\
\hline Accepted: April $16^{\text {th }}, 2018$ & $\begin{array}{l}\text { Rhizopus oryzea lipase. Lipase has been immobilized on celite by } \\
\text { absorption method. Immobilization experiments have been } \\
\text { designed in a two-level full factorial model with three factors. The } \\
\text { fish oil has been hydrolyzed with immobilized lipase to enrich } \\
\text { PUFA with optimized parameters found out: the ratio of enzyme }\end{array}$ \\
\hline $\begin{array}{l}\text { Keywords: } \\
\text { celite immobilized enzyme, } \\
\text { lipase, Pangasius } \\
\text { hypophthalmus, PUFA, } \\
\text { Rhizopus oryzea }\end{array}$ & $\begin{array}{l}\text { to support of } 1: 10 \mathrm{~g} / \mathrm{g} \text {, the ratio of phosphate buffer volume to } \\
\text { support the weight of } 30.55 \mathrm{ml} / \mathrm{g} \text {, the incubation time of } 5.15 \\
\text { hours. The result has shown that } 60 \text {-minute hydrolysis is the most } \\
\text { appropriate. Additionally, the oil iodine value has increased from } \\
71.4 \text { to } 97.4 \text {, and DHA concentration has risen from } 1156 \mathrm{mg} / \mathrm{kg} \\
\text { to } 1916 \mathrm{mg} / \mathrm{kg} \text {. }\end{array}$ \\
\hline
\end{tabular}

\section{Introduction}

In recent years, Pangasius hypophthalmus fillet has become the famous marine product of Vietnam. In the Mekong River Delta, the growing up of catfish fillet output has increased from 250 thousand to million tons. The byproducts of this industry namely head, tail, skin, bone and especially, fish oil has become waste. Every year, in this area, there are at least 30 thousand tons of fish oil releasing into the environment because the reuse of this byproduct in other industries is not efficient.

Catfish crude oil contains about $12.72 \%$ of PUFAs (Hoang, 1997) being much more than animal fat or coconut oil.

Polyunsaturated fatty acids (PUFAs) are essential for human beings, which we often could not synthesize. PUFAs like DHA or EPA would be enriched by many methods such as: isolating with supercritical solvent, fractionating with urea complexation, selective hydrolysis with lipase,... 
Among these, the lipase method is the safest for the environment and offers a product with the best quality.

Shimada, Maruyama, Sugihara, Moriyama, and Tominaga (1997) hydrolyzed tuna oil with microorganism lipases. Rhizopus delemar lipase acted moderately on the DHA ester, and the hydrolysis extent was only $25.7 \%$. DHA could not be recovered efficiently in the FFA fraction by hydrolysis with Candida lipase, so the percentage of DHA in this fraction was 36.8\%. The results showed that all Pseudomonas lipases acted strongly on the ester bond of DHA and that the hydrolysis extents were high from 59.3 to $71.9 \%$ DHA.

Oil hydrolysis with lipase is a complicated process. Triglycerides (oil) do not dissolve in the water phase, so the reaction has to take place at the interface of the water and lipid. Therefore, in order to increase the interfacial area of the oil-in-water emulsion, emulsifiers are added. Additionally, Murty, Bhat, and Muniswaran (2002) used immobilized enzyme instead of free enzyme combined with emulsion makes the reaction more efficient.

Lipase could be immobilized on support in some ways: absorption, cross-linking, binding, entrapment. The research of Soares, Castro, De Moraes, and Zanin (1999) showed that Candida rugosa lipase was immobilized by covalent binding on controlled pore silica (CPS) with glutaraldehyde. Protein retention and immobilization efficiency were in turn $60 \%$ and $18 \%$.

Rakshit, Vasuhi, and Kosugi (2000) enriched PUFA from tuna oil by Pseudonomas fluorescens immobilized lipase with 3 different methods: hydrolysis, esterification of fish oil FFA with alcohols (ethanol, propanol, octanol, glycerol) and transesterification between ethanol and fish oil. In the hydrolysis process, the time was changed from 2.25 to 48 hours. Generally, the weight percentage of DHA and EPA increased in FFA fraction and decreased in glyceride fraction throughout the hydrolysis process. After 48 hours, $80 \%$ of DHA was transferred to the FFA fraction.

In 2005, Linder, Fanni, and Pamentier hydrolyzed salmon oil with Aspergillus oryzea lipase. Lipolysis of the oil was carried out with Novozym SP398 to obtain a mixture of free fatty acids and acylglycerols ( 24 hours, $45 \%$ hydrolysis). The mixture was filtered on a hydrophobic membrane to discriminate between high melting saturated fatty acids and low melting acylglycerols. The sum of polyunsaturated fatty acids increased from $41.6 \%$ in the crude oil to $46.5 \%$ in the permeate.

Fernández-Lorente et al. (2011) immobilized lipase from Yarrowia lipolytica and Pseudomonas fluorescens on hydrophobic porous supports in order to enrich DHA in sardine oil. The most effective overactivation obtained in the work ranged from 6- to 20-fold.

In another report by Fernánndez-Lorente et al. (2011), absorption immobilized lipases from Candida antarcticia, Rhizomucor miehei and Thermomyces lanuginose were researched on the capability of increasing the concentration of PUFA in sardine oil.

\section{Materials and method}

\section{Material}

Pangasius hypophthalmus oil was bought from Thien Phat Company in Tien Giang 
province, Vietnam. The fatty acid of the crude fish oil was neutralized by $4 \%$ sodium hydroxide solution to get the acid value of $3.75 \mathrm{mgKOH} / \mathrm{g}$ oil. The iodine value was $71.4 \mathrm{~g}$ iodine $/ 100 \mathrm{~g}$ oil, DHA content was $1156 \mathrm{mg} / \mathrm{kg}$ oil.

Rhizopus oryzae lipase from Sigma-Aldrich $\left(\mathrm{pH}_{\mathrm{opt}}=7,0 ; \mathrm{T}_{\mathrm{opt}}=37^{\circ} \mathrm{C}, 1000 \mathrm{U} / \mathrm{g}\right.$ enzyme $)$. Celite 545 from Sigma-Alrich was used as the support for enzyme immobilization.

\section{Immobilization of lipases on celite (Kumar \& Kanwar, 2010)}

Celite was washed three times with Tris buffer $0.05 \mathrm{M} \mathrm{pH} 7.0$ to remove soluble impurities. The celite-545 (1g), preequilibrated in a volume of Tris buffer $(0.05 \mathrm{M}, \mathrm{pH} 7.0)$, was incubated with commercial lipase (Rhizopus oryzae). The celite-bound lipase (1g) was tested the activity and then used to hydrolysis catfish oil.

\section{Determination of lipase activity (Soares et al., 1999)}

The activities of free and immobilized lipase were tested with the soya oil emulsion as the substrate. The substrate was prepared by mixing $50 \mathrm{~mL}$ of the soya oil with $50 \mathrm{~mL}$ of emulsification reagent. The reaction mixture consisting of $5 \mathrm{~mL}$ of the emulsion, $2 \mathrm{~mL}$ of 100 $\mathrm{mM}$ sodium phosphate buffer, $\mathrm{pH} 7.0$, and either free $(1 \mathrm{~mL})$ or immobilized $(500 \mathrm{mg})$ lipase was incubated for $30 \mathrm{~min}$ at $37^{\circ} \mathrm{C}$. The reaction was stopped by the addition of $10 \mathrm{~mL}$ of acetone-ethanol solution (1:1). The liberated fatty acid was titrated with $25 \mathrm{mM}$ potassium hydroxide solution in the presence of phenolphthalein as an indicator.

One unit (U) of enzyme activity was defined as the amount of enzyme that produces 1 $\mu \mathrm{mol}$ of free fatty acid/min under the assay conditions.

\section{4)}

Two-level full factorial model for optimization of lipase immobilization (Yemata,

The levels of each factor were chosen so as to cover a range of values of practical interest.

\section{Table 1}

Experimental design layout

\begin{tabular}{cccc}
\hline Order & Factor 1 (Z1) & Factor 2 $(\mathbf{Z 2})$ & Factor 3 $(\mathbf{Z 3})$ \\
\hline 1 & + & + & + \\
\hline 2 & + & + & - \\
\hline 3 & + & - & - \\
\hline 4 & + & - & + \\
\hline 5 & - & - & - \\
\hline 6 & - & + & - \\
\hline 7 & - & - & + \\
\hline 8 & - & + & + \\
\hline
\end{tabular}

Source: The researcher's data analysis

To minimize the effect of variability in the response due to extraneous factors, the experiments were performed in random order.

The analysis of results was carried out using the statistical software Design Expert 7 
(DX7).

After run data from Table 2 with DX7, the polynomial model was derived:

$$
\begin{aligned}
& y=\alpha_{0}+ \\
& \sum_{\mathrm{i}=1}^{3} \alpha_{\mathrm{i}} \mathrm{x}_{\mathrm{i}}+\sum_{\mathrm{i}=1}^{3} \sum_{\mathrm{j}=\mathrm{I}+1}^{3} \alpha_{\mathrm{ij}} \mathrm{x}_{\mathrm{i}} \mathrm{x}_{\mathrm{j}}+\alpha_{123} \mathrm{x}_{1} \mathrm{x}_{2} \mathrm{x}_{3}
\end{aligned}
$$

The statistical significance of the model and coefficients were also determined in DX7.

Hydrolysis of catfish oil and purification glyceride fraction (Shimada, Maruyama,

\section{Sugihara, Moriyama, \& Tominaga, 1997)}

Some lipase, especially lipase from the organism, could enrich PUFAs in oil because they de-esterify firstly the saturated fatty acids. When the PUFA concentration decreases, the hydrolysis continues with the monounsaturated fatty acids, at last, the PUFAs. Because of that, when control the hydrolysis time, the PUFA-rich oil can get in the glyceride fraction while saturated and monounsaturated fatty acids become free fatty acids.

After finding out the optimum parameters in lipase immobilization, the enzyme was used to hydrolyze catfish oil. The hydrolysis time was increased from 30 to 120 minutes. The substrate was prepared by mixing $50 \mathrm{~mL}$ of the catfish oil with $50 \mathrm{~mL}$ of emulsification reagent. The reaction mixture consisting of $100 \mathrm{~mL}$ of the catfish oil, $50 \mathrm{~mL}$ of $100 \mathrm{mM}$ sodium phosphate buffer, $\mathrm{pH} 7.0,50 \mathrm{ml}$ emulsification reagent and $1 \mathrm{~g}$ immobilized lipase was incubated at $37^{\circ} \mathrm{C}$.

After hydrolysis, FFA was neutralized by sodium hydroxide solution. Then, the glyceride fraction was isolated by extracting with n-hexane and purified by evaporation. The glyceride fraction, at last, was determined the iodine value and DHA concentration evaluate the PUFA enrichment by lipase hydrolysis.

\section{Determination of iodine value}

Method for the determination of iodine value $(\mathrm{g} / 100 \mathrm{~g})$ of catfish oil and glyceride fraction after hydrolysis according to Wijs as indicated by AOAC Official Methods of Analysis (1984), Chapter 28.023.

Dissolve the sample in CCl4, add $25 \mathrm{~mL} \mathrm{Wijs} \mathrm{solution} \mathrm{and} \mathrm{keep} \mathrm{in} \mathrm{the} \mathrm{dark} \mathrm{for} 1$ hour to complete the reaction. Add deionized water and titrate excess iodine with $0,1 \mathrm{~N}$ sodium thiosulphate solution.

\section{Determination of DHA}

Method for the determination of DHA content in catfish oil is hydrolytic extraction gas chromatography method by AOAC Official Methods 966.06 (2010) for fat analysis in food.

\section{Results and discussion}

\section{Optimization of Rhizopus oryzea lipase immobilization on celite by absorption}

The two-level full-factorial design was used to evaluate the effect of the three main process parameters: the ratio of enzyme to support $(\mathrm{g} / \mathrm{g})$, the ratio of phosphate buffer volume to support the weight $(\mathrm{ml} / \mathrm{g})$ and the incubation time (hours). 


\section{Table 2}

Factors and levels of the experimental design

\begin{tabular}{lccc}
\hline \multirow{2}{*}{ Factor } & \multirow{2}{*}{ Unit } & \multicolumn{2}{c}{ Level } \\
\cline { 3 - 4 } & & $\mathbf{+ 1}$ & $\mathbf{- 1}$ \\
\hline The ratio of enzyme to support $(\mathrm{Z} 1)$ & $(\mathrm{g} / \mathrm{g})$ & $1: 17$ & $1: 33$ \\
\hline $\begin{array}{l}\text { The ratio of phosphate buffer volume to support weight ratio } \\
\text { (Z2) }\end{array}$ & & 50 & 20 \\
\hline Incubation time $(\mathrm{Z} 3)$ & (hours) & 3 & 1 \\
\hline
\end{tabular}

Source: The researcher's data analysis

With 3 factors and 2 levels for each factor, $\mathrm{N}=2^{3}=8$ experiments were done to get the practical activity of immobilized lipase.

The lipase activities of eight experiments in the two-level full factorial design are shown in Table 3. The analysis of results was carried out by the statistical software DX7.

Table 3

Lipase activities obtained at the experimental conditions

\begin{tabular}{ccccc}
\hline Order & Factor 1 (Z1) & Factor 2 (Z2) & Factor 3 (Z3) & $\begin{array}{c}\text { Enzyme activity } \\
\text { Y }(\mathbf{U I} / \mathbf{g})\end{array}$ \\
\hline 1 & + & + & + & 8.33 \\
\hline 2 & + & + & - & 12.99 \\
\hline 3 & + & - & - & 13.32 \\
\hline 4 & + & - & + & 11.66 \\
\hline 5 & - & - & - & 9.99 \\
\hline 6 & - & + & - & 12.49 \\
\hline 7 & - & - & + & 5.33 \\
\hline 8 & - & + & + & 6.33 \\
\hline
\end{tabular}

Source: The researcher's data analysis

By removing the non-significant terms from the full polynomial model, the simplified expression forms as below:

$Y(U I / g)=7,145+110 . X_{1}+0,186 . X_{2}-3,6 . X_{3}-2,867 X_{1} . X_{2}+54,167 . X_{1} . X_{3}-0,021 . X_{2} . X_{3}(2)$

With $\mathrm{R}^{2}=0.9995 ; \mathrm{cv} \%=1.72$ and $\mathrm{p}$-value of the model $=0,0416<0.05$.

A good agreement is found between experimental and calculated yields with $R^{2}=0.9995$ and $\mathrm{p}$-value of the model $<0.05$. The $\mathrm{cv}$ of the regression model is 1.72 , this $\mathrm{cv}$ value indicates that the factual activity of the experiment does not have too much variation.

Equation 2 also includes the coefficients associated with three main factors. Hence, all of the factors have effects on enzyme activity. There are the coefficients of X1.X2; X1.X3 and $\mathrm{X} 2 . \mathrm{X} 3$ in the model, the existence of those coefficients shows that the three factors not only affect the activity but also interact with each other to change the lipase activity. 
Depending on the regression model, the optimized immobilized lipase activity in this situation have been $22.95 \mathrm{UI} / \mathrm{g}$ with:

- The ratio of enzyme to support (Z1): 1:10 (g/g);

- The ratio of phosphate buffer volume to carrier weight (Z2): $30.55 \mathrm{ml} / \mathrm{g}$;

- Incubation time (Z3): 5.15 hours.

These optimum parameters have been used to immobilize lipase from Rhizopus oryzea in the next step of this research.

\section{Effect of hydrolysis time on PUFA enrichment}

Catfish oil was hydrolyzed with immobilized lipase in 0, 30, 60, 90 and 120 minutes. The iodine value of the glyceride fraction was determined by the Wijs method. The result was analyzed with Stagraphic 3.0 software. The iodine value of the glyceride fraction was shown in Table 4.

\section{Table 4}

Iodine value of glyceride fraction after hydrolysis

Hydrolysis time (minutes)
Iodine value (g iodine/100g glyceride fraction)

\begin{tabular}{ll}
\hline 0 & $72.12^{\mathrm{c}}$ \\
\hline 30 & $89.08^{\mathrm{b}}$ \\
\hline 60 & $98.30^{\mathrm{a}}$ \\
\hline 90 & $97.40^{\mathrm{a}}$ \\
\hline 120 & $99.21^{\mathrm{a}}$ \\
\hline
\end{tabular}

Note: a, b, c statistically significant difference between the parameters in the column (p-value $<0.05$ )

Source: The researcher's data analysis

The crude catfish oil has had a lower iodine value than the hydrolysis glyceride

\section{Table 5}

Iodine value and dha concentration in catfish oil and glyceride fraction

\begin{tabular}{cccc}
\hline Order & Parameters & The glyceride fraction & The crude oil \\
\hline 1 & Iodine value & $97.42 \mathrm{~g}$ iodine $/ 100 \mathrm{~g}$ & $71.40 \mathrm{~g}$ iodine $/ 100 \mathrm{~g}$ \\
2 & DHA concentration & $1916 \mathrm{mg} / \mathrm{kg}$ & $1156 \mathrm{mg} / \mathrm{kg}$ \\
\hline
\end{tabular}

Source: The researcher's data analysis

The iodine value and DHA concentration in the glyceride fraction is higher than in the 


\section{Conclusion}

The immobilized process of Rhizopus oryzea lipase has been optimized and the immobilized lipase has had the activity of about $22 \mathrm{UI} / \mathrm{g}$. When hydrolyzing the crude Pangasius hypophthalmus oil in 60 minutes, both the iodine value and DHA concentration has been increased in turn 26.02 units and $760 \mathrm{mg} / \mathrm{kg}$. This enzyme selectively hydrolyzed oil in the initial phase, so it could be used to enrich PUFA in oil like fish oil.

\section{ACKNOWLEDGEMENTS}

I would like to express my great appreciation to the Faculty of Biotechnology and the Office of Cooperation and Research Management, Ho Chi Minh City Open University for supporting us in our project. I would also like to extend my thanks to the technicians of the Faculty of Biotechnology for their help in offering me the resources in running the experiments.

\section{References}

Fernández-Lorente, Betancor, L., Carrascosa, A. V., \& Guisan, J. M. (2011). Release of omega3 fatty acids by the hydrolysis of fish oil catalyzed by lipases immobilized on hydrophobic supports. Journal of the American Oil Chemists' Society, 88, 1173-1178.

Fernández-Lorente, Pizarro, C., Lopez-Vela, D., Betancor, L., Carrascosa, A.V., Pessala, B., \& Guisan, J. M. (2011). Hydrolysis of fish oil by lipases immobilized inside porous supports. Journal of American Oil Chemistry's Society, 88, 819-826.

Freitas, L., Bueno, T., Perez, V. H., Santos, J. C., \& Castro, H. F. (2007). Enzymatic hydrolysis of soybean oil using lipase from different sources to yield concentrated of polyunsaturated fatty acids. World Journal of Microbiology and Biotechnology, 23, 17251731.

Ganhdi, N. N. (1997). Applications of lipase. Journal of the American Oil Chemists' Society, 74(6), 621-634.

Kumar, A., \& Kanwar, S. S. (2010). Synthesis of ethyl ferulate in organic medium using Celiteimmobilized lipase. Bioresource Technology, 102, 2162-2167.

Hoang, D. N. (1997). Dầu thực vật và sức khỏe [Vegetable oil and health]. In Trung tâm Dinh duỡng Trẻ em Thành phố Hồ Chí Minh (pp. 12-15).

Linder, M., Fanni, J., \& Pamentier, M. (2005). Proteolytic extraction of salmon oil and PUFA concentration by lipases. Marine Biotechnology, 15, 70-76.

Murty, V. R., Bhat, J., \& Muniswaran, P. K. A. (2002). Hydrolysis of oils by using immobilized lipase enzyme: A review. Biotechnology and Bioprocess Engineering, 7, 57-66.

Rakshit, S. K., Vasuhi, R., \& Kosugi, Y. (2000). Enrichment of PUFA from tuna oil using immobilized Pseudonomas fluorescens lipase. Bioprocessing Engineering, 23(2000), 251-255.

Shimada, Y., Maruyama, K., Sugihara, A., Moriyama, S., \& Tominaga, Y. (1997). Purification of Docosahexaenoic acid from tuna oil by a two-step enzymatic method: Hydrolysis and selective esterification. Journal of the American Oil Chemists' Society, 74(11), 14411446. 
Soares, C. M. F., Castro, H. F. D., De Moraes, F., \& Zanin, G. M. (1999). Characterization and utilization of Candida rugosa lipase immobilized on controlled pore silica. Applied Biochemistry and Biotechnology, 79, 745-757.

Ustun, G., Guner, S., Arer, G., Turkay, S., \& Erciyes, A. (1997). Enzymatic hydrolysis of anchovy oil: Production of glycerides enriched in PUFA. Applied Biochemistry and Biotechnology, 68, 171-186.

Yemata, T. A. (2014). Optimisation of acid hydrolysis in ethanol production from Prosopis juliflora. American Journal of Energy Engineering, 2(6), 127-132. 